\title{
Zuckerman \& Calobrisi - Introduction to the Special Issue on Buddhism \& the History of Science
}

\author{
Thomas Calobrisi $^{1} \cdot$ Devin Zuckerman ${ }^{2}$
}

Published online: 10 February 2020

(C) The Author(s), under exclusive licence to Springer Nature Switzerland AG part of Springer Nature 2021

We would like to begin this brief introduction with an anecdote, which we believe will be illustrative of the importance of the studies contained in this special issue of the Journal of Dharma Studies. When, in late January of this year, the World Health Organization declared the novel coronavirus (COVID-19) a public health emergency of international concern, the ways that Buddhist monastic communities in and around Kathmandu, Nepal, responded were consistent with the public health protocols of most secular institutions at the time: the compulsory use of masks, hand-sanitizing, and temperature-taking at entry points, as well as total closure monastic facilities to the public - a measure that seemed drastic at the time. However, alongside these measures, there was a distinctly religious and ritual response to pandemic: the coordination of massive $p \bar{u} j \bar{a} s$ at the Boudhanath stüpa, often sponsored by wealthy international donors, conducted to avert the further spread of the virus both locally and globally, as well as the dispensation and circulation of protective amulets by Tibetan medical institutions. Buddhists monastic communities in Kathmandu thus availed themselves of all the resources at their disposal: evidence-based public health practices which we might identify as "scientific" as well ritual and contemplative practices which we might construe as "religious."

We introduce this special issue citing this anecdote because, for one, it would seem inappropriate not to mention the ways the COVID-19 pandemic has loomed large over the editorial process and the daily lives of our global communities over the past year. It is also apropos to the nature of the project we have proposed for this issue: to consider how Buddhist communities across space and time have produced and validated knowledge about the world around them and their place within it. Contributions to this special issue seek to explore forms of knowledge, their production, and validation in the Buddhist world which have fallen through the cracks as well as to challenge the way in which Buddhist forms of knowledge about the natural world have been presented in Western scholarship for the past century and a half.

Thomas Calobrisi

tcalobrisi@ses.gtu.edu

1 Graduate Theological Union, Berkeley, CA, USA

2 University of Virginia, Charlottesville, VA, USA 
To be more specific, the contributions to this special issue challenge the colonial-era discourse of "Buddhism as a science of the mind," which itself has led to the "Buddhism and science dialogue" that has accelerated significantly since the late 1980s. The discourse of "Buddhism as a science of the mind," constructed as a response to the pressures of European colonial hegemony and Christian missionary presence across Asia, puts Buddhist beliefs and practices (themselves profoundly reshaped along the lines of Protestant Christianity) into conversation with an idealized version of scientific knowledge and its practices of production to claim Buddhism is an "inner science" equipped with rigorous methods of experimentation and observation equal to the "outer science" of the West. This presentation of Buddhism has within the last few decades come under serious scrutiny from scholars in the field of Buddhist studies. ${ }^{1}$ Nonetheless, an unfortunate effect of the influence of the discourse of "Buddhism as a mind science" is that it has seriously marginalized Buddhist forms of knowledge production which have sustained Buddhist communities throughout history. Guided by methodological insights from the history of science, which sees "science" as a body of historically contingent, culturally prescribed practices as well as a body of ever-changing knowledge, contributions to this special issue seek to uncover and present a "Buddhist history of science" which brings to the fore those forms of knowledge which have been under-considered in academic scholarship thus far.

Republished with a new preface, our first essay of the special issue, "Buddhism and the Sciences: Historical Background and Contemporary Development" by Richard K. Payne, provides a critical overview of the historical and contemporary interaction between "Buddhism" and "Science." Payne traces developments that have taken place over the last three decades within academic Buddhist studies as well as within popular Buddhist knowledge and practice in the West. He acknowledges the way that the study of Buddhism has become more nuanced, involving deeper understanding and interest in Buddhism as a "complex intellectual culture," thereby releasing it from the constraints of being a "religion." This, he observes, has opened new avenues of inquiry into Buddhist knowledge traditions, and the ways that these intersect with other scientific practices in history. Payne writes about the topics of embryology and medicine, environmental sciences, calendrics and logic, in particular. He also writes about how, alongside and in relationship with the growing interest in Buddhist knowledge production, there has been a secularizing impulse in the popular practice of Buddhism in the West.

Julia Stenzel's essay, "The Sciencization of Compassion," examines the "sciencization," as the author puts it, of compassion and the Tibetan Buddhist contemplative practices that aim at its cultivation. She traces the conditions for the "scientization" of compassion to Tibetan works of the eleventh and fourteenth centuries, when such practices were simplified and popularized as a practice for lay people. The simplification and popularization of Buddhist ideas and practices, she argues, serves as a precondition to their being "scientized," as these processes serve to align said ideas and practices to practical and worldly concerns of lay people. Sciencization

\footnotetext{
${ }^{1}$ See, David L. McMahan, The Making of Buddhist Modernism (New York: Oxford University Press, 2008); David L. McMahan, Erik Braun, eds., Meditation, Buddhism, and Science (New York: Oxford University Press, 2017); and Donald S. Lopez, Jr., Buddhism and Science: A Guide for the Perplexed (Chicago: University of Chicago Press, 2008).
} 
has thus become one more step in the translation of Buddhist practices for the more worldly concerns of lay people living in the modern West.

"The Chinese Buddhist Approach to Science: The Case of Astronomy and Calendars" by Jeffrey Kotyk explores the relationship of Buddhist monastics to astrological knowledge practices in China in the first millennium CE. The article demonstrates that Chinese Buddhist monastics were not heavily invested in the study and innovation of the astral sciences in China for a variety of reasons, including, the author tells us in the introductory moments of the essay, a difference in intellectual and mathematical tools within Buddhist scripture, as well as legal prohibitions against the study of astrology, and a reluctance to canonize these knowledge systems. The figure of Yixing (683-727 $\mathrm{CE}$ ), who was a Buddhist monk and court astronomer, illustrates the compartmentalization of the "secular" knowledge practice of astronomy and the religious knowledge practices of Buddhism.

Sonam Kachru's essay "Seeing in the Dark: Of Epistemic Culture and Abhidharma in the Long Fifth Century CE" explores the engagements with Buddhist Abhidharma philosophy by two figures from the "long fifth century CE," Skandhila and Vasubandhu. Borrowing terminology from the Austrian sociologist of science Karin Knorr-Cetina, Kachru seeks to understand the "epistemic culture" of Abhidharma during a critical period for the development of Indian Buddhist philosophy. ${ }^{2}$ This is to say, he seeks to understand not only how knowledge is produced and justified within Abhidharma philosophy and its commentarial literature but also how the heterogeneity of the means of knowledge-making is elided in its retroactive organization and unification. By looking at disagreements among these Abhidharma thinkers, Kachru not only uncovers the heterogeneity elided in the composition of Abhidharma epistemic culture but is also able to identify the unique "styles of knowing" present in Abhidharma philosophy. The upshot of Kachru's fascinating study is that the epistemic culture of Abhidharma philosophy and its styles of knowing in first millennium CE India are themselves highly contingent on the soteriological implications of the temporal distance of Skandhila and Vasubandhu to Sākyamuni Buddha and to the very nature of the Buddha's dharma as both teaching and explication.

The final essay of the special issue, "The Offering of Mount Meru: Contexts of Buddhist Cosmology in the History of Science in Tibet" by Michael Sheehy, considers the importance of Mount Meru cosmology for Tibetan Buddhists from the seventeenth century to the present. Sheehy is particularly concerned with the claim by the 14th Dalai Lama Tenzin Gyatso in his 2005 book The Universe in a Single Atom that parts of Buddhist cosmology which do not conform to modern scientific cosmology ought to be abandoned and the implications of this proclamation for Tibetan Buddhist thought and practice. ${ }^{3}$ Challenging the conventional history which has the eccentric Buddhist monk Gendun Chöpel (1903-1951) introduce Tibetans to the Western model of the spherical earth in the early twentieth century, Sheehy shows that Tibetans had been aware of Western science as early as the seventeenth century when Jesuit missionaries

\footnotetext{
${ }^{2}$ Karin Knorr-Cetina, Epistemic Culture: How the Sciences Make Knowledge (Cambridge: Harvard University Press, 1999).

3 Tenzin Gyatso, The Universe in a Single Atom: The Convergence Between Science and Spirituality (New York: Broadway Books, 2005), 80.
} 
were introducing Western astronomy, calendrics, and mathematics to China, and that serious reckoning with this knowledge in Tibet came in the centuries following.

Tracing out the Tibetan engagement with Western science in eighteenth and nineteenth centuries, Sheehy shows that Western cosmology, with its spherical earth, did not cause Tibetans to abandon traditional Buddhist cosmology but sparked a cosmopolitan impulse of curiosity for foreign cultures and to envision themselves within a broader human world and cosmos. Following this, Sheehy returns to the contemporary moment and the Dalai Lama's claim regarding the abandonment of certain points of Buddhist cosmology. He critically examines the Dalai Lama's further claim that the "Buddhism and science dialogue" is really one between modern science and "Buddhist science," exploring the contradictory implications of presenting Buddhist cosmology and teachings as both sensorily evident, empirically testable third-person knowledge of the natural world and trans-empirical insight that is primarily liberative in character rather than simply descriptive. In concluding his study, Sheehy stresses the need for each side of the Buddhism and science dialogue to consider and appreciate the history and contexts of their respective ideas as well as the different virtues of their epistemic cultures.

Due to the circumstances under which this special issue came together (the COVID19 pandemic) and the new demands that it has placed on those doing research and teaching in the academy, many of those whom we had invited to contribute were not able to do so. Nonetheless, the essays included here are more than enough to chart out new ways of writing Buddhist intellectual history and thinking about the nature of knowledge and its production in the Buddhist world, past and present. Also included in this issue are two articles on topics other than Buddhist histories of science: "The Power of Shared Breath: an Irigarayan Reading of Prāṇa in Vedānta and Sāṃkhya Philosophies" by Ana Laura Funes Maderey, and "Like a Bee to Nectar: Abhinavagupta's Poetics of Religious Formation" by Ben Williams. We also include here three book reviews: a review of Debanshish Banerji's What, and Who, Ever Am I? by Alicia Gonzales; a review of Thomas Nathan Patton's The Buddha's Wizards: Magic, Protection, and Healing in Burmese Buddhism by Beiyin Deng; and a review of Parveen Jain's An Introduction to Jain Philosophy by Jeffery D. Long.

We are deeply grateful to the Journal of Dharma Studies editorial manager, Laura Dunn, for her ever-patient guidance of the two of us through the peer-review and editorial processes as well as the co-editors-in-chief, Dr. Rita Sherma and Dr. Purushottama Bilimoria, for granting us the opportunity to publish this special issue with the Journal of Dharma Studies.

Publisher's Note Springer Nature remains neutral with regard to jurisdictional claims in published maps and institutional affiliations. 